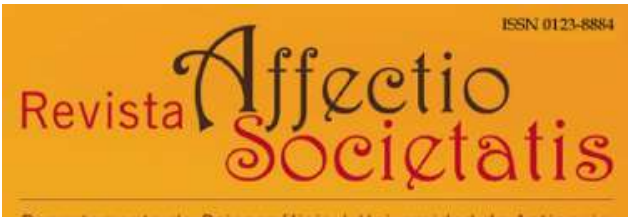

Departamento de Psicoanálisis | Universidad de Antioquia

Revista Affectio Societatis

Departamento de Psicoanálisis

Universidad de Antioquia

revistaaffectiosocietatis@udea.edu.co

ISSN (versión electrónica): 0123-8884

Colombia

Revista Affectio Societatis, Vol. 16, № 30, enero-junio de 2019

Art. \# 8 (pp. 144-173)

Departamento de Psicoanálisis, Universidad de Antioquia Medellín, Colombia 


\title{
SOBRE O ESQUECIMENTO INESQUECÍVEL DA VOZ DO OUTRO: SUPEREU, OBJETO VOZ E MÚSICA
}

\author{
Lucas Emmanoel Cardoso de Oliveira ${ }^{1}$ \\ Pontifícia Universidade Católica do Rio de Janeiro, Brasil \\ lucas emmanoel@yahoo.com \\ ORCID: 0000-0001-9081-8081 \\ Marcus André Vieira² \\ Université Paris Diderot, Paris \\ mav@litura.com.br \\ ORCID: 0000-0002-0383-8218
}

DOI: 10.17533/udea.affs.v16n30a08

\section{Resumo}

O presente artigo tem como objetivo não está referido à Lei, mas ao gozo apresentar o objeto voz na psicanálise. Verificamos que a manifestação eminente do objeto voz é a incidência das vozes do supereu, o qual

exigido pelo Outro absoluto, revelando-se na vociferação no sujeito neurótico acometido pelo destilhaçamento fantasístico, e na alucinação

1 Graduado em Psicologia na Pontifícia Universidade Católica de Goiás, na qual produziu o trabalho: Narcisismo e Anorexia (2010); psicanalista associado ao Corpo Freudiano Escola de Psicanálise do Rio de Janeiro; mestre em psicologia clínica pela Pontifícia Universidade Católica do Rio de Janeiro, onde defendeu a dissertação: Sobre o esquecimento inesquecível da voz do Outro: o objeto voz na psicanálise (2017), com a orientação do professor Marcus André Vieira; e músico pelo Instituto de Educação em Artes Professor Gustav Hitter-GO.

2 Psicanalista; psiquiatra pela Université Paris Diderot, PARIS 7, França; mestrado e doutorado em Diplôme D'études Approfondies en Psychanalyse pela Université Paris 8; Membro da EBP - Escola Brasileira de Psicanálise - e da AMP - Associação Mundial de Psicanálise; professor do programa de Graduação e Pós-graduação em psicologia na Pontifícia Universidade Católica do Rio de Janeiro. 
do sujeito psicótico. Nesse sentido, apreendemos a experiência com as vozes do supereu como o elo indicativo da fraternidade entre neurose e psicose. Diante disso, e para ambos os casos, pudemos sugerir que a música, envolvida no trabalho de transferência, pode se colocar como um dispositivo para o esquecimento das vozes do supereu, ao mesmo tempo em que, também com a música, se reafirma o quão inesquecível foi entrar no gozo com o Outro.

Palavras-chave: objeto a; supereu; objeto voz; música.

\section{SOBRE EL OLVIDO INOLVIDABLE DE LA VOZ DEL OTRO: SUPERYÓ, OBJETO DE VOZ Y MÚSICA}

\section{Resumen}

El presente artículo tiene como objetivo presentar el objeto voz en el psicoanálisis. Comprobamos que la manifestación eminente del objeto voz es la incidencia de las voces del superyó, el cual no está referido a la Ley, sino al goce exigido por el Otro absoluto, revelándose en la vociferación en el sujeto neurótico acometido por el despedazamiento fantástico y en la alucinación del sujeto psicótico. En este sentido, entendemos la experiencia con las voces del superyó como el eslabón indicativo de la fraternidad entre neurosis y psicosis. Ante esto, y para ambos casos, podemos sugerir que la música, implicada en el trabajo de transferencia, puede usarse como un dispositivo para el olvido de las voces del superyó, al mismo tiempo que, también con la música, se reafirma cuán inolvidable fue entrar en el goce con el Otro.

Palabras clave: objeto a; superyó; objeto voz; música.

\section{ON THE UNFORGETTABLE OBLIVION OF THE VOICE OF THE OTHER: SUPEREGO, OBJECT VOICE AND MUSIC}

\section{Abstract}

This paper aims at presenting the object voice in psychoanalysis. We verify that the eminent manifesta- tion of the object voice is the effect of the voices of the superego, which is not related to Law, but to the jou- 
issance demanded by the absolute Other, revealing in the shouting in the neurotic subject assailed by the fantastic tearing and in the hallucination of the psychotic subject. In this sense, we understand the experience with the voices of superego as the link indicative of the fraternity between neurosis and psychosis. For both cases, we suggest that music, involved in the transference work, may be used as a device to forget the voices of the superego, and, at the same time, with music too, it is reaffirmed how unforgettable was the entrance in the jouissance with the Other.

Keywords: object a, superego, object voice, music.

\section{SUR L'OUBLI INOUBLIABLE DE LA VOIX DE L'AUTRE: SURMOI, VOIX D'OBJET ET MUSIQUE}

\section{Résumé}

Cet article a pour but de présenter l'objet voix dans la psychanalyse. L'on constate que la manifestation éminente de l'objet voix est l'incidence des voix du surmoi. Celui-ci ne se réfère pas à la Loi, mais à la jouissance exigée par l'Autre absolu, qui se manifeste en la vocifération chez le sujet névrosé assailli par le déchirement fantastique, et en l'hallucination chez le sujet psychotique. Dans ce sens, l'expérience avec les voix du surmoi apparaît ici en tant que maillon indicatif de la fraternité entre névrose et psychose. Pour les deux cas, l'on suggère que la musique impliquée dans le travail de transfert peut être utilisée en tant que dispositif pour l'oubli des voix du surmoi et que, en même temps, elle réaffirme le caractère inoubliable du fait de renter dans la jouissance avec l'Autre.

Mots-clés : objet a, surmoi, objet voix, musique. 


\section{Introdução}

Este artigo $^{3}$ objetiva apresentar o objeto voz que se manifesta, sobretudo, através da incidência no sujeito das vozes do supereu. Assim, no primeiro tempo deste artigo, apresentaremos algumas notas sobre os comparecimentos da voz nas contribuições freudianas, dando ênfase às injunções das vozes do supereu. No segundo tempo, além de fazermos considerações sobre o objeto $a$, indicaremos algumas especificidades do objeto voz, destacando o fato de que o ouvido é o único orifício do corpo que não pode se fechar; o que alude para a característica do supereu de invadir o sujeito, evocando assim ao gozo da continuidade primordial infans-Outro absoluto. Essa continuidade é testemunhada tanto pelo sujeito neurótico quanto pelo psicótico, fraternidade tal que pode ser reconhecida a partir da experiência com as vozes do supereu. Diante disso, no terceiro tempo, iremos sugerir que a experiência do sujeito com a música, envolvida no trabalho de transferência, se colocaria como possibilidade de esquecimento da vociferação do Outro, ato que implica, concomitantemente, no quão inesquecível foi entrar na continuidade com a voz do Outro.

\section{Algumas notas sobre a voz (a)sonora em Freud}

Mesmo reconhecendo o fato de Lacan ter elevado a voz ao estatuto de conceito, apreendendo-a como objeto pulsional ${ }^{4}$, postulamos que

3 O presente artigo é parte da dissertação "Sobre o esquecimento inesquecível da voz do Outro: o objeto voz na psicanálise" apresentada em 2017, com a orientação do professor Marcus Andre Vieira e produzida no projeto "A voz e os limites: aspectos de uma alteridade sem corpo", na Pontifícia Universidade Católica do Rio de Janeiro (PUC-RIO). Por isso, agradeço a acolhida de todos os envolvidos, além da Coordenação de Aperfeiçoamento de Pessoal de Nível Superior (CAPES) por ter concedido a bolsa de mestrado e ao programa de pós-graduação em psicologia clínica da PUC-RIO.

4 O estatuto da voz como objeto pulsional faz referência à voz como objeto $a$, como foi formulado por Lacan no seminário A angústia (1962-1963/2005). A voz, juntamente com o objeto olhar, foram incluídos na série de objetos estabelecidos por Freud: oral e anal. A abordagem do objeto voz será realizada posteriormente. 
o lugar de importância conferido à voz - tanto na sua manifestação sonora quanto não-sonora, na clínica psicanalítica e na constituição do sujeito - foi inaugurado por Freud, ainda que este não tenha se detido especialmente sobre o tema. Para manifestar aquela importância, faremos alguns apontamentos sobre a associação livre, a afonia na histeria, o grito, a fantasia, o silêncio, a alucinação, para enfim, adentrarmos nas vozes do supereu.

O lugar de importância da voz - tanto no encadeamento significante presente na fala quanto no afeto como efeito da musicalidade da voz -, na psicanálise, coincide com a própria fundação desta. O poder de hipnotizar conferido ao médico no "teatro charcotiano" foi destituído pela histérica Emmy Von N. (Breuer \& Freud, 18931895/1996, p. 83), quando esta disse a Freud: "Fique quieto! Não diga nada! Não me toque!". Em outro momento, quando Freud a indagou sobre de onde provinham as suas dores gástricas, a paciente, em um claro tom de queixa, disse a Freud que ele não deveria lhe perguntar de onde provinha isso ou aquilo, mas que a deixasse contar o que tinha a dizer (Breuer \& Freud, 1893-1895/1996, p. 83). Freud concordou e ela prosseguiu. Ele se deixou ensinar pelas falas dos analisandos, reconhecendo a importância da fala para o tratamento analítico, denominado pela Srta. Anna O. de "talking cure" e, ainda, de "chimney-sweeping" (Breuer \& Freud, 1893/1996, p. 65). Esse fato foi uma via privilegiada para Freud vislumbrar a invenção da psicanálise através da associação livre, na qual o sujeito é convidado a falar o que quiser, sem ater-se ao sentido. Podemos dizer, assim, que o sujeito justifica o acontecimento do inconsciente quando se põe a falar, pois é aí que ele, como sujeito do inconsciente, se perde, reafirmando o fato de que "não é senhor de sua própria casa" (Freud, 1916-1917 [19151917]/1996, p. 153).

Nesse ato de fala, que pressupõe sempre um Outro, sob todas as sortes de mal-entendidos, a materialidade sonora da voz pode, também, se tornar áfona, ausentar-se, ficar rouca, reafirmando o quão ela é despossuída pelo falante, indicando para um modo de dizer sobre o indizível que incide no corpo, como próprio da experiência do inconsciente. Na dimensão sonora da fala, ressaltamos o lugar do corpo, o qual é o substrato orgânico onde se faz o exercício da fala, mas, 
sobretudo, o lugar onde se revela o indeterminado da pulsão, indicando aí um perigo para a voz. Como Arnaud (1992, p.26) indica: “O perigo para a voz vem sempre do corpo. Seu único lugar real de exercício e também seu único perigo". A inconformidade do corpo fura a fala, e isso não foi imperceptível a Freud, comparecendo nos casos clínicos, como no caso da Srta. Rosalia H. (1893-1895/1996) e de Dora (1905[1901]/1996), em que a perda da fala é um indicativo da conversão histérica, ou como um dos modos do inconsciente se revelar na peculiaridade histérica de produzir um desejo insatisfeito, o qual comparece no seu corpo através da perda da função de um órgão.

A sonoridade da voz também comparece no grito do vivente na experiência primordial de satisfação (Freud, 1950[1895]/1996, p. 370) que se põe como abertura para o Outro. Da satisfação experimentada, restou das Ding, como impossibilidade de reencontrar esse objeto satisfatório. É nesse encontro com o Outro, que implica sempre em um desencontro, que o organismo do vivente é Outrificado, processo pelo qual o faz experimentar a passagem do "grito puro ao grito para" (Poizat, 1996, p.191), marcando a inauguração do sujeito na linguagem. Enquanto no "grito puro" o vivente grita como resposta ao inominável da necessidade, no "grito para" há o apelo ao Outro com a malograda visada de repor a satisfação decorrente da ação específica.

Além disso, podemos indicar a importância da experiência com o que se escutou para a constituição da fantasia. Freud, na sua reflexão sobre a arquitetura da histeria presente no Rascunho L (1950 [18921899]), do dia 2 de maio de 1897, além de destacar a fantasia como uma função defesa, postulará uma divisão sensorial para a produção da fantasia e do sonho, indicando que, enquanto o que se escutou constitui o núcleo da fantasia, o sonho se produz a partir do que se viu. Conforme seus escritos: “(...) As fantasias são feitas de coisas que são ouvidas e posteriormente utilizadas; (...) Relacionam-se com coisas ouvidas, assim como os sonhos se relacionam com coisas vistas. Nos sonhos, realmente, não ouvimos nada, nós vemos" (Freud, 1950 [1892-1899]/1996, p. 297).

Partindo do pressuposto de que a fala é um suporte privilegiado para o encadeamento significante - mas não exclusivo -, o qual não 
é outra coisa senão, "aquilo em que se vê aprisionado um animal à procura de seu objeto, de tal modo que a busca desse objeto o conduz a um outro campo de rastros, no qual essa mesma busca perde seu valor introdutório e se transforma em seu próprio fim (Lacan, 1962$1963 / 2005$, p. 78), portanto, a fala situa-se no reino do equívoco. Isso se reafirma ainda mais na singularidade do modo em que o sujeito realizou a escuta das palavras e da sonoridade da voz, podemos dizer que a escuta convoca o sujeito a se posicionar, e nesse processo, a sua operação fantasística se revela. É nesse sentido que podemos apreender a indicação de Freud de quê o que se escutou constitui o núcleo da fantasia, embora, possamos apontar que não há gesto humano que não suscite a fantasia, além da audição, a visão, o tato, o paladar, o olfato. Assim, para além da experiência perceptiva, a fantasia é constitutiva do sujeito-Outro.

A sonoridade da voz também está referida ao silêncio, afinal, a produção sonora é constituída e só é possível com sons e silêncios. Essa coabitação interna entre fala e silêncio se desdobra na prática psicanalítica. Nesse sentido, do mesmo modo que a regra da associação livre constitui um fator de primeira importância para a análise, o silêncio também o é. Pois, à medida que o analista encarna esse silêncio, o faz como abertura para o acontecimento imbuído do porvir que implica sempre uma alteridade presente na fala e no silêncio do analisando. É importante notar que o silêncio do analisando não é desprovido de um dito, ainda que seja para aludir ao indizível. Caberia ao analista escutar a "música" que o analisando compõe e, em uma postura ética, relançar ao analisando a sua "produção musical", encorajando-o a escutá-la.

Em Freud, podemos indicar pelo menos três tipos de silêncios que podem se manifestar na clínica psicanalítica. Um se manifesta como resistência e faz referência a algo que foi silenciado em decorrência do recalque, o qual acontece "silenciosamente" (Freud, 1911/1996, p.78) e é tornado ruidoso somente no processo subsequente de restabelecimento no qual o recalque se desfaz. Assim, o silêncio do analisando, como manifestação de um não-dito proveniente do recalque, é ainda assim possibilidade de se dizer e encontrar sentido através da interpretação psicanalítica. O segundo silêncio está referido à angús- 
tia. Como Freud (1919/1996) aponta, o silêncio, assim como a solidão e a escuridão são elementos que fazem despontar a despersonalização angustiante característica do Unheimlich (1919/1996, p. 238) - estranho-familiar -, "aquela categoria do assustador que remete ao que é conhecido, de velho, e (...) familiar". O terceiro silênciovai para além do que foi silenciado pelo recalque, é destituído de sentido, é indicativo do silêncio estrutural da "pulsão de morte" (Freud, 1920/2006) - anunciado pela compulsão à repetição - que opera silenciosamente a sua destrutividade na intimidade do sujeito (Freud, 1930 [1929]/1996). Este silêncio é anterior e está subjacente ao par significante silêncio-som.

Das manifestações da voz apresentadas por Freud, é na alucinação na psicose que a voz terá um lugar eminente, o que se aproxima do objeto voz que será formulado por Lacan - o qual partiu da investigação das alucinações para cunhar o objeto voz. Na alucinação as vozes são experimentadas pelo sujeito como provenientes de uma terceira pessoa, que vociferam injunções no mesmo, determinando-lhe ordens que ressoam e são assumidas como verdades, essas vozes são vividas como um acontecimento de certeza que conduz o sujeito à obediência (Vieira, 2009). É importante sublinhar que essas vozes não são percebidas sensorialmente, não são sonorizadas - como foi apontado nas manifestações anteriores -, mas se fazem escutar internamente e silenciosamente em um repetitivo eco que invade e inunda esse sujeito psicótico, nadificando-o. Como o que é testemunhado pelo presidente Schreber em sua narração autobiográfica Memórias de um Doente dos Nervos (1905/1995), o que foi investigado por Freud em Notas psicanalíticas sobre um relato autobiográfico de um caso de paranóia (Dementia Paranoides) (1911/1996).

As vozes na alucinação aludem para as vozes do supereu, que não se restringem aos contornos simbólicos da lei edípica - como veremos em seguida -, mas é indicativo do pulsional manifestado pelo supereu que vocifera a sua tirania no sujeito. Assim, o presidente Schreber, desprovido da simbólica lei edípica que lhe forneceria resguardo frente às injunções do supereu, se encontra acometido pelos comandos insensatos das vozes alucinadas. Esse supereu de lei cega é figurado pelo pai da horda primitiva (Freud, 1913[1912-1913]/1996), 
o todo poderoso, não-castrado. O assassinato simbólico do pai primevo instituiria a Lei no psiquismo, como acontece na neurose, mas na psicose esse pai impiedoso não morre, encontra-se vivo e urra através das vozes alucinadas.

Em Freud, as vozes ganharão um maior contorno investigativo com o comparecimento do supereu, o qual se manifesta através das vozes que, silenciosamente, vociferam no eu, de modo íntimo e alheio a ele. Na complexidade que essa instância psíquica foi se dando na obra freudiana, podemos vislumbrar que, se por um lado o supereu encarna a lei edipiana, a qual resguardaria o eu da trágica indiferenciação entre o eu e o Outro; por outro, essa instância se põe como transgressão dessa lei, como uma "lei da não lei", lançando o eu, justamente, naquela indiferenciação.

Como grande parte das elaborações freudianas, as quais se abrem para uma contínua reformulação através do que se escuta na clínica, a apreensão do que veio a se nomear de supereu não se deu desde o início, o que será feito apenas em 1923 no texto O eu e o id. Contudo, desde outrora os seus traços puderam ser escutados por Freud. Conforme é sugerido por Gerez-Ambertín (2009), as manifestações do supereu já se anunciavam na psicanálise nos primeiros casos clínicos, em que comparecia a autopunição com a qual condescende todo sujeito que, na sua condição humana de desamparo, tem a dependência ao Outro como constitutivo da sua origem, justificando o masoquismo como originário; assim como nas reflexões de Freud em torno do parricídio e da culpa. O supereu vai emergir, nominalmente, dentro do que se considera como segunda tópica da produção freudiana, acompanhado pelo comparecimento do "demoníaco" da pulsão de morte em 1920, a qual subverteu o princípio do prazer até então soberano nas suas investigações da primeira tópica.

Inicialmente, e até os últimos textos de Freud, o supereu comparecerá equiparado ao ideal do eu; contudo, no processo investigativo desses operadores se despontarão algumas distinções; como veremos adiante.

No texto À guisa de introdução ao narcisismo (1914/2004), Freud indicará que as vozes estarão articuladas com a "consciência moral" 
(p.113). Essa consciência atua a partir do ideal do eu, referido aos modelos ideais da lei e da ética para os quais o eu vai se encaminhar na vida, na tentativa de assegurar a satisfação narcísica experimentada no tempo infantil em que, o infans, reafirmado pelo amor dos pais, se erigia como seu próprio ideal, pondo-se, onipotentemente, como eu ideal. A consciência moral teria a função de observar continuamente o eu, tendo como medida o ideal do eu, elevando o nível de exigências do mesmo. Além disso, Freud apontará que essa autocrítica da consciência moral coincide com o delírio de estar sendo observado, em que a paranóia experimentada pelo sujeito se caracteriza assim:

(...) todos os seus pensamentos são conhecidos, de que todos os seus atos são vigiados e supervisionados, de que vozes os informam da atuação dessa instância e, ainda, de que essas vozes lhes falam, caracteristicamente na terceira pessoa ("agora ela está pensando nisso de novo"; "agora ele vai embora") (Freud, 1914/2004, p. 114, grifos nossos).

Freud vai seguir reconhecendo que uma instância que opera como vozes internas, com um domínio que observa todas as intenções do sujeito e que tem acesso a elas e as critica, "de fato existe" e está "presente na vida normal de todos nós" (Freud, 1914/2004, p. 114).

Em Psicologia e a análise do ego (1921/1996), verificamos que ao mesmo tempo em que o ideal do eu trabalha para a restituição do asseguramento narcísico perdido, mediado pelo julgamento da consciência moral, paradoxalmente assume a expressão das funções de críticas injustificáveis e punitivas que esbravejam no eu, como no caso da melancolia, na qual o eu passa a experimentar uma "cruel autodepreciação do ego, combinada com uma inexorável autocrítica e acerbas autocensuras" (p.119). Ao contrário do ideal do eu, esta experiência melancólica testemunha um esgarçamento narcísico, através de uma instância que "se comporta tão cruelmente tampouco a desconhecemos" (p.119); o que remonta à operação do supereu, conforme Freud irá demonstrar no texto Eu e o id (1923).

Neste texto, Freud sublinha que, em decorrência da dissolução do complexo de Édipo, a proibição da indiferenciação no incesto que an- 
tes era feita pela instância parental - o terceiro ao duo mãe-bebê - é internalizada e se encontra como um precipitado proveniente das identificações parentais que modificará o eu, produzind o o "ideal do eu ou o supereu" (1923/2007, p.44) - aqui Freud ainda não faz a separação entre ambos. Dito isso, o supereu, apreendido aqui como legislador, é herdeiro do complexo de Édipo. Contudo, em seguida, Freud indicará que subjacente a este supereu edípico, "esconde-se a primeira e mais significativa identificação do indivíduo, aquela com o pai da sua própria pré-história pessoal" (p.42) que, para o autor, não parece ser decorrente de um "investimento objetal", mas de uma "identificação direta e imediata, anterior a qualquer investimento de objeto" (p. 42). Mais a frente, Freud vai indicar que o supereu "é produto da primeira identificação que ocorreu em um momento no qual o eu ainda era fraco; segundo, ele é o herdeiro do complexo de Édipo (...)" (p. 56).

O paradoxo entre ideal do eu e supereu e a evocação mitológica ao pai da pré-história, com o qual o eu se identifica, desafia o entendimento relançando mais questões. Ainda assim, acompanhando as indicações de Freud e as manifestações clínicas do supereu, este se revela "perenemente mais próximo do id e é capaz de representá-lo frente ao Eu" (1923/2007, p. 57), ao contrário do ideal do eu. Nesse sentido, a identificação pela qual o supereu se constitui não seria por assimilação, na qual traços do Outro são simbolicamente assimilados, mas por incorporação do pai da pré-história pessoal, que pode ser apreendido como testemunho do inassimilável. Portanto, podemos dizer que seria uma identificação por incorporação, "direta e imediata", da inexorável alteridade, instituída mitologicamente pelo pai sem rédeas e tirânico da horda primitiva tal como Freud apresenta em Totem e tabu (1913[1912-1913]/1996), e que se manifestará como "um resíduo, puro resto que se faz ouvir em um eco crítico" (Gerez-Ambertín, 2009,p. 64).

Indicando para esse supereu, que abriga em si o excesso do pulsional e que se distancia do ideal do eu, Freud fará menção à experiência melancólica, em que a destrutividade sádica se engendra no supereu, que, por conseguinte, se dirigi contra o eu. É nesse sentido que o autor apontará que no supereu existe "uma cultura pura da pulsão de morte" (1923/2007, p. 66). Desse modo, enquanto o eu tenta em 
vão "se defender contra as exigências de um id sanguinário e contra as acusações de uma consciência moral punitiva" (p.61), o supereu pode ser supermoral e tornar-se tão cruel como o id (Freud, p. 61).

Todavia, e a despeito do supereu tender a se conciliar com o ideal do eu, Freud vai questionar tal entendimento assumindo uma suspicácia quanto à "metamorfose do relacionamento parental em superego" (1933[1932]/1996, p. 68): "não nos sentimos seguros de que estejamos compreendendo-a por inteiro". Ainda assim, segue mantendo o supereu como uma produção edípica (1940 [1938]/1996) que instituiria a lei frente ao gozo, sendo, portanto, um fator civilizatório ${ }^{5}$.

Enquanto em Freud - mesmo com os apontamentos que diferenciam ideal do eu e supereu - verificamos a proeminência do supereu como "herdeiro do Complexo de Édipo", como interditor do gozo, Lacan, o conceberá como um "imperativo do gozo": "Nada força ninguém a gozar, senão o superego. O superego é o imperativo do gozo Goza!" (1975/1985, p. 11); o que se opõe ao ideal do eu e às interdições fundadas pela lei edipiana.

Nesse sentido, o imperativo conclamado pelo supereu não interdita o gozo, mas é a vociferação do próprio gozo tirânico que constrange e insulta o sujeito e o conduz a exceder os limites da lei rumo ao impossível do gozo, o que obstaculariza o desejo e a lei que o causa. Desse modo, o supereu nadifica o sujeito na sua possibilidade de enlace com o outro. Lacan (1953-1954/2009, p. 140) estabelecerá que:

O supereu é, a um só tempo, a lei e a sua destruição. Nisso, ele é a palavra mesma, o comando da lei, na medida em que dela não resta mais do que a raiz. A lei se reduz inteiramente a alguma coisa que não se pode nem mesmo exprimir, como o Tu deves, que é uma palavra privada de todos os seus sentidos. É nesse sentido que

5 Miller (1994) ratificará que o supereu freudiano não corresponde a uma função moralizante e legal. Este psicanalista, fazendo referência ao texto Uma descrição metapsicológica do processo de cura (1925), de Franz Alexander, apontará que o supereu, como um automatismo da repetição, não tem função de adaptação, mas de inadaptação do sujeito, ao exigi-lo o impossível da satisfação. 
o supereu acaba por se identificar àquilo que há somente de mais devastador, de mais fascinante, nas experiências primitivas do sujeito. Acaba por se identificar ao que chamo figura feroz, às figuras que podemos ligar aos traumatismos primitivos, sejam eles quais forem, que a criança sofreu.

Se a lei funda a falta, que é condição para o desejo e abertura para o Outro, o supereu a destrói vociferando um gozo que não admite dialética, pondo-se como um "Tu deves", mudo, sem sentido, que se aloja no eu como um "corpo estranho (...), (em que) o eu se crê no estado de duplo, isto é, expulso da casa enquanto o $t u$ fica sendo o possuidor das coisas" (Lacan,1957-1958/1999, pp. 212-313). O eu se põe como um servo masoquista e voluntário do supereu, o qual, sadicamente, lhe devasta e causa fascínio, encontrando aí o sentido para esta instância operar como imperativo do gozo, em que o eu nada mais faz que escutar, obedecer e servir ao supereu o seu corpo para neste deixar escorrer o gozo, experimentado como estranho, externo, mas, também, familiar, íntimo. É nesse sentido que o eu, ao sucumbir às agressões do supereu, se põe comparativamente como os protistas, "que são destruídos pelos produtos dos seus próprios processos internos de decomposição orgânica" (Freud, 1923/2007, p. 56).

Freud, reconhecendo a importância atribuída aos "restos-de-palavras pré-conscientes" na formação do eu (1923/2007, p. 60), questionará se o supereu é constituído através do que se escutou. Mesmo sem demarcar uma resposta definitiva e sem estabelecer uma relação direta entre o supereu e a experiência auditiva, ele estabelecerá que é impossível negar o fato de que o supereu se origina, também, "naquilo que já foi um dia escutado" (p. 60). E quanto à energia de investimento do supereu, Freud indicará que esta não provém de "eventuais percepções auditivas, lições ou leituras", mas de "fontes situadas no id" (p. 60).

Freud, assim, revela que o supereu se constitui através do "lóbulo auditivo" (1923/2007, p. 38), que é um receptáculo dos restos das palavras escutadas, dos fragmentos vocais, desprovidos de significação. E é justamente pela via de um sem sentido que o supereu se defronta com o eu e o vocifera com um "Tu deves", impossibilitando uma ela- 
boração que permita ao eu fazer frente aos imperativos destrutivos dessa instância que exige a ele um gozo insustentável. Além disso, Freud indica que a fonte de investimento, ou o que talvez pudéssemos nomear de "adesão pulsional" a esses restos de palavras que constituem o supereu advém das moções pulsionais do id. Em outros termos, o receptáculo psíquico para os restos ouvidos se abriga no id, reafirmando a singularidade do efeito no sujeito do que se escutou, mais do que propriamente foi ouvido. São esses restos de vozes, sem sentido que, embora sustentados pela linguagem, que silenciosamente e ao mesmo tempo em um estrondoso barulho, vão ecoar repetidamente no supereu, fazendo com que o eu, de imediato, apenas ouça e obedeça, porque "ouvir é obedecer" (Quinard, 1999, p. 64).

Esse excedente é indicativo do supereu, que se porá como um limite da linguagem na sua possibilidade de significação. Isto que resta da significação alude para o que Lacan denominará de objeto $a$, em que o supereu é uma de suas manifestações: "não pode haver concepção analítica válida do supereu que esqueça que em sua fase mais profunda a voz é uma das formas do objeto $a^{\prime \prime}$ (19621963/2005, p. 321).

\section{Objeto a, objeto voz}

No coração da subjetividade há uma falta de objeto pela qual o sujeito se inaugura como tal, passando a se endereçar eternamente na vida em busca desse objeto, que foi supostamente encarnado por uma "pessoa pré-histórica e inesquecível, e que jamais é igualada por ninguém posteriormente" (Freud,1896/1996, p. 287). Malgrado o sujeito, esse encontro, tido como um reencontro com aquilo que se perdeu, é experimentado no máximo como uma "nostalgia (que) liga o sujeito ao objeto perdido, através da qual se exerce todo o esforço da busca" (Lacan, 1956-1957/1995, p. 13). Desse modo, trata-se sempre de um desencontro, como um acontecimento irremediável da vida. A fantasia solicita a realização do desejo com o objeto e a vida dá o objeto $a$, que comparece como falta no interior do agalma e atualiza a inexis- 
tência de um objeto que venha suprir essa falta incurável e estrutural do sujeito; o que conduz o sujeito ao movimento desejante.

No Seminário 10, A angústia (1962-1963/2005), o objeto a receberá a sua mais categórica apreensão, será concebido como real, irrepresentável, que cai como resto irredutível à operação significante pela qual o sujeito se inaugura na linguagem.

A constituição do sujeito é decorrente da queda do objeto $a$, o qual marca a radicalidade da Lei da castração na carne do sujeito, tornando-o da linguagem, humanizando-o. Nesse processo o real do organismo do infans é envolvido e dividido pelos significantes que acompanham o desejo do Outro, e para isso, é preciso que o pequeno se deixe envolver por esse que lhe invoca, em um movimento duplo (Catão, 2015); o que levará a uma subtração do gozo do organismo de onde cairá o objeto $a$, como um "pedaço carnal arrancado de nós mesmos" (Lacan, 1962-1963/2005, p. 237).

No seminário 11, Os quatro conceitos fundamentais da psicanálise (1964), Lacan utiliza duas operações lógicas matemáticas para teorizar o processo de subjetivação: alienação e separação. O primeiro tempo é o da alienação, e está referido à reunião do vivente com o Outro, à sua alienação aos significantes que vêm do Outro, como condição mínima para a produção da primeira significação da qual o sujeito será efeito. O segundo tempo é o da separação, na qual o infans rompe a circularidade com o Outro que lhe determinava. Desse corte brotará um resíduo, um resto, impossível de ser simbolizado e que se mantém como "prova e garantia única (...) da alteridade do Outro" (Lacan, 1962-1963/2005, p. 36). Nesse processo, “(...) a voz é o produto, o objeto caído do órgão da fala" (Lacan,1962-1963/2005, p. 71).

Como resto do processo de subjetivação e marca do real, o objeto $a$ não tem representação no mundo, não é redutível à percepção, senão através das vestes imaginárias e simbólicas que o cobrem. Desse modo, o $a$ é um resto que está excluído da cadeia simbólica de significantes, ao mesmo tempo em que a sustenta, causando o encadeamento de um significante a outro no intento de produzir uma significação possível. Sendo assim, o objeto $a$ comparece como "extimidade" 
(Lacan, 1959-1960/2008, p. 173), como uma "exterioridade íntima" (p.173), tão íntima que estruturalmente é a mais exterior.

No seminário 10 o objeto $a$ será experimentado pelo sujeito como causa de desejo, no qual a inexistência de um objeto que venha suprir a pulsão encontra-se velada pela fantasia; como fonte de angústia, quando acontece o fracasso daquela fantasia neurótica fazendo irromper o anúncio da aproximação do gozo; e posteriormente, no seminário 16, De um Outro ao outro (1968-1969/2008), tal objeto incidirá no corpo como mais-de-gozar, indicativo do gozo da pulsão de morte que opera silenciosamente o seu destroçamento no sujeito através compulsão à repetição.

Essas experiências do sujeito com o objeto $a$ se darão através de alguns objetos referidos às zonas corporais por onde acontecem os encontros entre o sujeito e o Outro. À lista de objetos indicadas por Freud, seio, fezes, falo, Lacan acrescentou o olhar e a voz. Longe de concebê-los em uma evolução baseada em um substrato biológico, há, desde Freud um "anti-evolucionismo" (Vieira, 2009, p. 5) para o qual Lacan deu proeminência como uma das mostras da subversão que a psicanálise carrega no seu bojo. Desse modo, a experiência do sujeito com os objetos não pode ser apreendida de modo cronológico, em termos de "progressão ou de regressão" (Miller, 2013, p. 2), mas em termos estruturais, referido ao acontecimento entre sujeito e Outro; o que foi apresentando por Lacan (1964/2008) assim: o objeto oral é o objeto da demanda ao Outro; o objeto anal é o objeto da demanda do Outro; o objeto escópico é o objeto do desejo ao Outro; e o objeto voz é o objeto do desejo do Outro.

Da série de objetos $a$, conjecturamos que a experiência com o objeto voz é a que mais testemunha a continuidade sujeito-Outro, o gozo da alienação primordial. Como verificamos, todos os outros objetos têm essa propriedade, mas a voz, inelutavelmente, tem a especificidade de invadir o sujeito: "o corpo tem alguns orifícios, dos quais o mais importante é o ouvido, porque ele não pode se tapar, se cerrar, se fechar. É por esse viés que, no corpo, responde o que chamei de voz" (Lacan, 1975-1976/2007, p. 19). O que não comparece de modo tão manifesto em outros objetos: enquanto no nível do seio pode-se engolir ou cuspir; 
no nível do excremento pode-se regular, soltar ou reter as fezes; no olhar pode-se desviar ou movimentar as pálpebras; no objeto voz, o qual é contornado pela pulsão invocante ${ }^{6}$ operada pelas vozes do supereu que convocam ao gozo, o sujeito não tem pálpebras: "Antes do nascimento, até o instante derradeiro da morte, os homens e as mulheres ouvem sem um instante de descanso" (Quinard, 1999, p. 65).

Antes de retornar a essa especificidade da experiência com a voz, objetivamos fazer algumas considerações sobre as indicações de Lacan em torno do objeto voz.

O objeto voz lacaniano não está referido à sonoridade: “O que sustenta o $a$ deve ser bem desvinculado da fonetização" (Lacan, 19621963/2005, p. 273). Este é o paradoxo radical da voz na psicanálise, do objeto voz, que é áfono, e pode ser concebido como um conceito operativo referido à experiência subjetiva de ser acometido pelo indeterminado da pulsão invocante. Nesse sentido, o objeto voz comparece, à revelia do eu, nos mal entendidos da pretensa tentativa de reciprocidade na comunicação, nos atos falhos, nos lapsos da fala, nas repentinas crises de tosse e em súbita rouquidão, na gagueira, no grito, no pranto - como um limite do dito -, na experiência estética com a música - pois à medida que a música vela o pulsional da voz ela também se coloca como possibilidade de revelá-lo -, na angústia, nas alucinações, dentre outras manifestações.

Essa distinção entre o objeto voz e o sonoro é estabelecida por Miller (1989/2013, p. 12-13): “Se nós falamos tanto, se fazemos nossos colóquios, se conversamos, se cantamos e se ouvimos os cantores, se fazemos música e se a escutamos (...) é para fazer calar o que merece

6 Este termo foi utilizado pela primeira vez por Lacan no Seminário 11 (1964/2008, p. 105), na aula A linha e a luz, em 4 de março de 1964, e ratificou o termo, além de ter mencionado outros, na aula O que é um quadro?, em 14 de março de 1964: “invocante, vocatório, vocacional" (1964/2008: 118). Mas foi com Didier-Weill que esse termo ganhou eminência e foi desenvolvido, a partir da intervenção deste no seminário 24 de Lacan: L'Insu que sait de l’une-bévue s’aile à mourre, em 21 de dezembro de 1976, que resultou no texto Quand la musique nous entend: contribution à la question de la pulsion invoquante. 
que se chame a voz de objeto $a^{\prime \prime}$. Ainda assim, e por isso mesmo, consideramos que não há uma completa dissidência entre o objeto $a$ e o sonoro, pois à medida que o imaginário da sonoridade da voz e o seu encadeamento simbólico tentam calar o real do objeto voz, o próprio movimento de mantê-lo à distância carrega no seu ato o que lhe terrifica - o real da voz.

Outra indicação de Lacan é que, a pulsão invocante, a qual tem o objeto voz como a sua correspondente, é apreendida por Lacan como “a experiência mais próxima do inconsciente" (1964/2008, p.105); o que pode ser compreendido na reafirmação de que o inconsciente se funda no acontecimento entre o organismo e o Outro, e que este, representado por um outro semelhante comparece primordialmente através da voz (Laznik, 2000, 2004; Catão \& Vivès, 2011), da qual não há escapatória (Lacan, 1975-1976/2007).

Lacan (1964/2008, p. 118) apontará também que no terceiro tempo da pulsão, que é o se fazer ao Outro, "o se fazer ver indica por uma flecha que verdadeiramente retorna para o sujeito, ao passo que o se fazer ouvir vai para o outro", é invocação ao Outro. E o autor ressalta que a razão disso é de estrutura, ou seja, o que se fala vai direto para o Outro, e não há retorno, pois o som "tem uma existência efêmera que se extingue mal começa" (Hegel, 1974, p. 195), "é uma exteriorização que se destrói a si mesma e no próprio momento em que nasce" (Hegel, 1974, p. 181). E pelo fato do se fazer ouvir ir para o Outro, este ato está implicado no desejo. Como Lacan indica, no seminário 13, O objeto da psicanálise, na lição do dia 1 de junho de 1966, o objeto voz está diretamente implicado no nível do desejo; logo, o que entra em questão na experiência com a voz é o desejo do Outro. Assim ele afirma: "Se o desejo do sujeito se funda no desejo do Outro, este desejo como tal se manifesta no nível da voz". E nesse mesmo entendimento o psicanalista segue indicando que: "A voz não é somente o objeto causal, é também o instrumento pelo qual se manifesta o desejo do Outro". Destarte, à medida que a voz utilizada como instrumento manifesta o desejo, ela também é evocação do real do objeto voz.

Outro apontamento sobre a voz, é que esta “(...) não é assimilada, mas incorporada (Lacan,1962-1963/2005, p.301), para dizer do modo 
que o supereu se constitui e opera na subjetividade, sem a mediação simbólica. Enquanto o processo de assimilar faz referência ao ato de se apropriar de algo, tornando-o elemento da composição de uma substância que se pretende idêntica ao que foi assimilado, a incorporação se revela na radical não-identidade, referido ao real do Outro como um pedaço de corpo estrangeiro que é incorporado quando a constituição do sujeito, operando neste de modo intrusivo, testemunhando a inexorável alteridade; o que é indicativo do funcionamento do supereu. Esta indicação de Lacan reporta ao que Freud já havia mencionado no texto Eu e o id (1923) para dizer da constituição do supereu, em que subjacente ao eu ideal esconde-se a primeira e mais significantiva identificação, que é por incorporação, com o pai da pré-história pessoal do eu. Nessa apreensão e conforme desenvolvemos até aqui, podemos dizer que subjacente ao contorno simbólico do eu ideal há o real do supereu.

É nesse sentido também que Lacan (1964/2008, p. 118) postulará que na pulsão invocante, ao contrário da pulsão escópica, o sujeito se encontra determinado; o que alude ao mandato das vozes do supereu que exige gozo ao sujeito e o mantém nadificado.

Por fim, a característica que consideramos mais específica da experiência com o objeto voz é o fato de o ouvido ser o único orifício que não pode se fechar para o que vem do Outro (Lacan, 1975-1976/2007), metaforizando a experiência de continuidade sujeito-Outro, em que o interno e o externo se encontram pouco delineados; o que nos conduz a afirmar, junto com Dolar (2000), que existe algo do fenômeno psicótico em toda voz.

Para o sujeito se constituir como tal foi preciso que esta continuidade, referida ao gozo, se tornasse descontínua, como produção significante de cortes pelos quais o desejo emergiria; ou ainda, que o Outro absoluto, por efeito da Lei, se convertesse em Outro barrado, o qual, apostando que naquele organismo pudesse haver um saber, possibilitou a produção de um lugar para o surgimento do sujeito que, no mesmo movimento, pudesse se esquecer da voz do Outro absoluto que é imperativo de gozo. Todavia, esse ato de esquecer só foi possível porque ele previamente foi receptor do real da voz do 
Outro (Didier-Weill, 1997, p.37): “da mesma forma que, para escrever, é preciso uma página branca, para falar é necessário um esquecimento, um branco, um silêncio absoluto do Outro, sem o qual a fala não pode ressoar". Ainda assim, reafirmamos que o fato do sujeito ter sido receptor da voz do Outro absoluto, como condição para ele advir, revela o quão inesquecível foi gozar com essa voz, a qual pode ser testemunhada pela vociferação do supereu no sujeito neurótico quando este, em experiências contingenciais da vida, é vivido pelo destilhaçamento da fantasia, a qual se colocaria como um modo de velar o real do objeto voz, e nas alucinações do sujeito psicótico que indicam o eterno fracasso da fantasia.

Desse modo, reconhecemos nessa experiência com as vozes do supereu uma fraternidade entre neurose e psicose. O que é vivido pelo neurótico é "comparável" mas não "idêntico" a uma "alucinação" (Didier-Weill,1997, p.137); o que pode ser traduzido assim: "Onde está você, que não cessa de me esquecer?", o que é "traumatizante na medida em que questiona o esquecimento fundador da existência", onde os limites entre o sujeito e o Outro se encontram diminuídos.

Nesse sentido, o recalque originário (Freud, 1915/2004), como um primeiro esboço da descontinuidade na continuidade fundadora do sujeito, não se faz de uma vez por todas, tendo que ser atualizada em um movimento espiral ${ }^{7}$ que acompanha o próprio processo de humanização, sobretudo cada vez que o sujeito é nadificado e tornado objeto pela vociferação do Outro.

E como derivado da operação do recalque originário se institui o "ponto surdo" (Vivès, 2012a), um ponto intra-psíquico que reafirma a operação pela qual o sujeito, após gozar na continuidade da voz do Outro primordial e absoluto, precisou se tornar surdo a esta voz, para assim, constituir um campo perceptivo e escutar como sujeito do inconsciente. Ou seja, sem um ponto surdo o sujeito estaria imerso no real do gozo oceânico e mortífero das vozes das sereias, do supereu;

7 Esse entendimento foi sugerido pela Inês Catão na ocasião da defesa de dissertação de mestrado da qual este artigo partiu. 
o que estancaria a sua invocação desejante da vida. Podemos dizer que naquele movimento espiral que partiu do recalque originário, situam-se, além do ponto-surdo, as fantasias, que velam o real da falta de objeto e é via para o enlace com o outro (Lacan, 1958-1959/2016).

A importância desse movimento subjetivador de reafirmar o esquecimento da voz do Outro põe o acabamento do Édipo incessantemente em questão. E o testemunho psicótico não nos deixa esquecer essa não garantia do processo simbólico edípico. É nesse seguimento que Porge (2014, p. 59) nos convida a "reconsiderar a neurose do ponto de vista da psicose e não o inverso, como de costume". Desse modo, apreendendo a história da psicanálise como um procedimento que na sua construção se fez crítica ao seu próprio fazer, partir da escuta da psicose é reconhecer esta como uma constatação de que "teoria é bom, mas não impede que as coisas existam" (Charcot, 1892-1894, p.210, citado por Freud, 1893-1895/1996, p.23).

Destarte, sugerimos que, para aquele esquecimento da voz do Outro, a experiência com música, pode se colocar como um via possível.

\section{Vozes do supereu, objeto voz e música}

Lacan (1962-1963), inspirado nas investigações de Theodor Reik (1946) sobre o instrumento chofar - utilizado em várias circunstâncias da antiguidade, mas que se tornou circunscrito às liturgias judaicas do ano novo e do dia do perdão - apreendeu este rito para "substantivar" (Lacan, 1962-1963/2005, p.268) a sua apreensão sobre o objeto voz. Dentre as suas reflexões, a sonoridade do chofar remeteria à renúncia ao gozo, evocaria a morte do pai totêmico (Freud, 1913 [1912-1913]/1996), o qual alude ao Deus absoluto que comparece através das vozes do supereu. Assim, a execução desse instrumento na liturgia se poria como barra à vociferação do supereu. E ao passo que a sonoridade desse instrumento vela a presença das vozes do supereu, ele também as revela, mantendo a força da presença do Deus onipotente, o rastro do assassinato, mas de modo localizado e ritmado. 
Seguindo esta indicação de Lacan sobre a função do chofar, sugerimos que a música - ouvida, cantada e tocada ${ }^{8}$-, envolvida pela transferência, pode se pôr como um dispositivo para reconstituir o ponto surdo no neurótico que, por contingências da vida, experimentou o destilhaçamento fantasístico e se oferecer como um "lugar tenente" ${ }^{\prime \prime}$ (Vivès, 2016,p. 3) - uma suplência para o recalque originário que não aconteceu na psicose - às alucinações do psicótico, como possibilidade de esquecimento da voz do Outro, não para fazê-las desaparecer, mas para localizar o gozo, sustentá-lo e fazer algo diferente com o mesmo. Schreber assim o fez e, no seu escrito autobiográfico, nos transmitiu que a música pode ser uma dessas formas. Ele tocava piano (Schreber, 1905/1995, p.242).

Assim, ao mesmo tempo em que a música faria ensurdecer a voz do Outro arcaico, ela também lhe daria voz; pois, nesse contexto, à medida que a produção musical seria propulsionada por essa tentativa de esquecer a vociferação do Outro feroz, esse próprio fazer permitiria escutar o real do supereu, este resto traumático que diz sobre o mais íntimo do sujeito, contudo, velado pelas propriedades imaginárias e simbólicas da música, referidas, respectivamente, ao sonoro e à linguagem pela qual a música se estrutura. Nos dizeres de Didier-Weill (1997, p.264): “(...) a música é essa presença pela qual é-nos lembrada que, em nossa tentativa de esquecer o Outro, somos obrigados a encontrar um ponto de onde o Outro, ao se subtrair a

8 De acordo com Vivès (2012c), o potencial terapêutico da música é uma questão antiga que se coloca desde o tempo de Hipócrates. Os gregos antigos destacaram que certos modos musicais - formas de organizar os sons - propiciavam o entusiasmo aos sujeitos. No século XIX, Pinel fazia escutar música nos hospitais psiquiátricos. E em torno dos anos 40, nos Estados Unidos, a musicoterapia instituiu-se como disciplina. A ideia desse dispositivo terapêutico seria que, quando o paciente escutasse certos tipos de música, isso permitiria modificar o comportamento. Hoje em dia, os estudos feitos a partir dessa perspectiva não são muito convincentes. Assim, este autor indica que a música não cura ou trata, para ele, o que trata é a transferência, contudo, a música pode ser utilizada em uma relação transferencial (Vivès, 2012b).

9 Este lugar foi proferido por Lacan no seminário O ato psicanalítico (1967-1968), na aula do dia 28 de fevereiro de 1968, onde ele indica que o "lugar tenente" (p.179) se colocaria como suplência ao recalque originário. 
nossa vontade de esquecimento, manifesta-se como coisa inesquecível, inegável".

Para apresentar o que desenvolvemos até aqui, propomos as seguintes ilustrações:

1. A primeira ilustração, que alude aos primórdios do sujeito, o infans está submetido aos caprichos do Outro absoluto. Portanto, inicialmente não há lugar para a emergência do sujeito, ainda que essa continuidade de gozo seja condição antecedente e lógica para o porvir de um sujeito. Postulamos que esta experiência de continuidade será atualizada na vociferação do supereu, o qual comparece sem a mediação da lei, no neurótico e nas alucinações do psicótico.

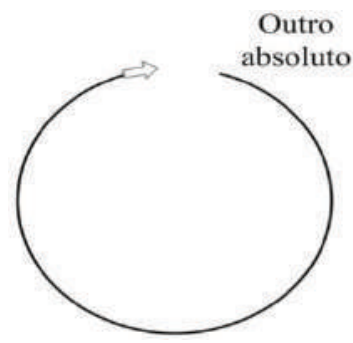

Figura 1: Quando o Outro é absoluto não há lugar para o sujeito.

Fuente: elaboração própria.

2. A segunda ilustração faz alusão à constituição do sujeito. Para este emergir é preciso que aquela continuidade seja barrada. Este processo irá reafirmar o ponto surdo, indicativo da operação recalque originário. Desse modo, através da barra da Lei, uma descontinuidade se faz na continuidade de modo a produzir um lugar de onde o infans irá emergir como sujeito, esquecendo-se da voz do Outro absoluto. Contudo, destacamos para o fato de que na ilustração abaixo, a barra da Lei não é contínua, para indicar que ela não se encontra, nunca, inteiramente intransponível; o contrário disso seria postular o engodo da garantia da Lei edípica. Esse entendimento reafirma que o objeto voz, através das vozes do supereu, está sempre à espreita de comparecer ao sujeito, ou ainda, que o ato de esquecimento implica no quão inesquecível foi o gozo da continuidade da voz do Outro absoluto. 


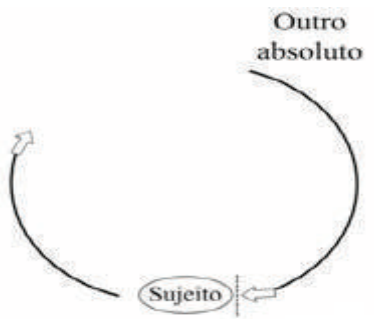

Figura 2: Constituição do sujeito.

Fuente: elaboração própria.

3. E justamente pelo fato do esquecimento da voz do Outro ser inesquecível, fomos conduzidos a questionar: e quando o ponto-surdo deixa de ensurdecer? E quando o sujeito é vivido pelo destilhaçamento da fantasia, sem a possibilidade, se quer, de formular uma resposta para o enígma do desejo do Outro? O sujeito é invadido pelas vozes do supereu que exigem gozo e o conduz para um gozo mortífero. Junto com Didier-Weill (1997), reconhecemos nessa experiência uma fraternidade entre neurose e as alucinações na psicose, justamente pelo acontecimento de certeza que se manifesta em ambas experiências. Assim, sugerimos que a música, envolvida na transferência, pode se colocar como barra à vociferação do Outro absoluto: como possibilidade de reconstituir o ponto surdo no sujeito neurótico e produzir um lugar-tenente para o psicótico, de modo a produzir um lugar onde o sujeito possa se posicionar frente às vozes do supereu que vocifera um saber absoluto sobre ele com um: "não, não sou apenas isso" (Didier-Weill, 1997), e assim, em um movimento desejante, possa invocar a vida.

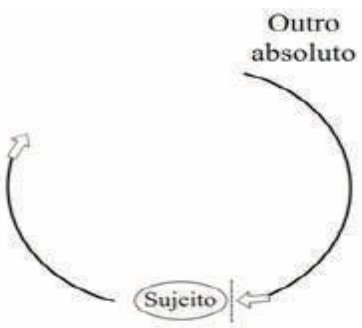

Figura 3: As vozes do supereu e a música.

Fuente: elaboração própria. 


\section{Considerações finais}

Reconhecemos que, em relação aos outros objetos, a experiência com o objeto voz, indicativo das vozes do supereu, seja a que mais se aproxima da continuidade sujeito-Outro; o que pode ser evidenciado no excesso de supereu no sujeito neurótico e na alucinação no sujeito psicótico, reafirmando a inexorável alteridade que destitui o eu de ser "senhor da sua própria casa” (Freud, 1916-1917 [1915-1917]/1996, p.153).

Lacan, em Alocução sobre as psicoses da criança (1967/2003, p.362), indicará que "toda formação humana tem por essência, e não por acidente, refrear o gozo". A música, com as suas propriedades imaginárias e simbólicas, pode se pôr como um freio neste gozo operado pelas vozes do supereu. Contudo, a despeito do risco de um refreamento ascético do gozo, que pode conduzir à conformidade mortificadora do sujeito, a música, ao apontar para o real (Didier-Weill, 1997; Azevedo, 2007), suscita esse mesmo gozo. Afinal, o humano nunca se contém completamente nos freamentos, pois ele é sempre incitado a renovar o gozo com a voz do Outro arcaico e absoluto: podemos dizer que esse seja o princípio do movimento circular da pulsão invocante (Vivès, 2012c, p.20; Didier-Weill, 2016, p.40); o que reitera que o esquecimento dessa voz é, inelutavelmente, inesquecível.

Assim, sugerimos que a música, envolvida pela transferência, seja uma via para a transformação deste gozo aniquilador em um gozo vital, fazendo-o fluir, esteticamente, em uma produção inventiva em torno daquilo que produzia o sintoma ou faria irromper a loucura. E que assim o sujeito siga invocando a vida, impulsionado pelo objeto voz, reconstruindo lugares fora de si, fora daquela casa onde ele, narcisicamente, presumia ser senhor.

\section{Referências}

Arnaud, A. (1992). Les hasards de la voix. Paris, France: Flammarion.

Azevedo, R.M. (2007). Vestígios do impossível - refletindo sobre música a partir da psicanálise. Dissertação de mestrado não publicada. Universidade Fe- 
deral do Norte Fluminense Darcy Ribeiro, Campos dos Goytacazes, RJ, Brasil. Recuperado em: http://www.dominiopublico.gov.br/pesquisa/DetalheObraForm.do?select_action=\&co_obra=177202.

Breuer, J. \& Freud, S. (1893-1895/1996). Casos clínicos. In: J. Strachey (Ed.) e J. Salomão (Trad.). Edição Standard Brasileira das Obras Psicológicas Completas de Sigmund Freud (Vol. II, pp.82-133). Rio de Janeiro, Brasil: Imago.

Catão, I. \& Vivès, J. M. (2011). Sobre a escolha do sujeito autista: voz e autismo. Estudos de Psicanálise, 36, 83-92. Recuperado em: http:/ / pepsic. bvsalud.org/pdf/ep/n36/n36a07.pdf.

Catão, I. (2015). O corpo como resposta à invocação da mãe. Revista Psicologia, Diversidade e Saúde, 4(1), 21-26. Recuperado em: https://www5. bahiana.edu.br/index.php/psicologia/article/view/665/519.

Didier-Weill, A. (1976/2015). Quand la musique nous entend: contribution à la question de la pulsion invoquante. In: Insistance. Quand la note bleue entend linconscient, 10, 15-20. Recuperado em: https://www.cairn. info/revue-insistance-2015-2-page-15.htm.

Didier-Weill, A. (1997). Os três tempos da lei: O mandamento siderante, a injunção do supereu e a invocação musical. Rio de Janeiro, Brasil: Jorge Zahar.

Didier-Weill, A. (2016). Qu`est-ce que le surmoi? Toulouse, France: Érès.

Dolar, M. (2000). Somos todos ventríloquos. In: D. A. Teixeira (Trad.). Disponível em: <https:/ /avrapalavra.com/2015/11/13/mladen-dolar-somos-todos-ventriloquos/>.

Freud, S. (1950 [1892-1899]/1996). Rascunho L, Notas I. Extratos dos documentos dirigidos a Fliess. In: J. Strachey (Ed.) e J. Salomão (Trad.). Edição Standard Brasileira das Obras Psicológicas Completas de Sigmund Freud (Vol. I, p.297). Rio de Janeiro, Brasil: Imago.

Freud, S. (1950 [1895]/1996). Projeto para uma psicologia científica. In: J. Strachey (Ed.) e J. Salomão (Trad.). Edição Standard Brasileira das Obras Psicológicas Completas de Sigmund Freud (Vol. I, pp.335-469). Rio de Janeiro, Brasil: Imago.

Freud, S. (1893-1895/1996). Charcot. In: J. Strachey (Ed.) e J. Salomão (Trad.). Edição Standard Brasileira das Obras Psicológicas Completas de Sigmund Freud (Vol. III, pp.19-34). Rio de Janeiro, Brasil: Imago.

Freud, S. (1896/1996). Carta 52. In: J. Strachey (Ed.) e J. Salomão (Trad.). Edição Standard Brasileira das Obras Psicológicas Completas de Sigmund Freud (Vol. I, pp.281-287). Rio de Janeiro, Brasil: Imago.

Freud, S. (1897/1996). Rascunho L. Notas 1. In: J. Strachey (Ed.) e J. Salomão (Trad.). Edição Standard Brasileira das Obras Psicológicas Completas de Sigmund Freud (Vol. I, pp.297-300). Rio de Janeiro, Brasil: Imago.

Freud, S. (1905[1901]/1996). Fragmento da análise de um caso de histeria. In: J. Strachey (Ed.) e J. Salomão (Trad.). Edição Standard Brasileira das 
Obras Psicológicas Completas de Sigmund Freud (Vol. VII, pp.75-98). Rio de Janeiro, Brasil: Imago.

Freud, S. (1911/1996). Notas psicanalíticas sobre um relato autobiográfico de um caso de paranóia (Dementia Paranoides). In: J. Strachey (Ed.) e J. Salomão (Trad.). Edição Standard Brasileira das Obras Psicológicas Completas de Sigmund Freud (Vol. XII, pp.15-92). Rio de Janeiro, Brasil: Imago.

Freud, S. (1913[1912-1913]/1996). Totem e tabu. In: J. Strachey (Ed.) e J. Salomão (Trad.). Edição Standard Brasileira das Obras Psicológicas Completas de Sigmund Freud (Vol. XIII, pp.13-168). Rio de Janeiro, Brasil: Imago.

Freud, S. (1914/2004). À guisa de Introdução ao narcisismo. In: A. H. Luiz (Trad.). Escritos sobre a psicologia do inconsciente. (Vol. I, pp. 95-131). Rio de Janeiro, Brasil: Imago.

Freud, S. (1915/2004). O recalque. In: A. H. Luiz (Trad.). Escritos sobre a psicologia do inconsciente. (Vol. I, pp. 175-194). Rio de Janeiro, Brasil: Imago.

Freud, S. (1916-1917[1915-1917]/1996). Conferências introdutórias sobre psicanálise (Parte I e II). In: J. Strachey (Ed.) e J. Salomão (Trad.). Edição Standard Brasileira das Obras Psicológicas Completas de Sigmund Freud. (Vol. XVI, pp.13-229). Rio de Janeiro, Brasil: Imago.

Freud, S. (1919/1996). O Estranho. In: J. Strachey (Ed.) e J. Salomão (Trad.). Edição Standard Brasileira das Obras Psicológicas Completas de Sigmund Freud (Vol. XVII, pp. 233-276). Rio de Janeiro, Brasil: Imago.

Freud, S. (1920/2006). Além do princípio do prazer. In:H.A, Luiz (Trad.). Escritos sobre a psicologia do inconsciente. (Vol. II, pp. 123-198). Rio de Janeiro, Brasil: Imago.

Freud, S. (1921/1940). Massen-psychologie und ich-analyse. In: Gesammelte Werke(Vol. XIII, pp.71-161). London, England: Imago.

Freud, S. (1921/1996). Psicologia de grupo e a análise do ego. In: J. Strachey (Ed.) e J. Salomão (Trad.). Edição Standard Brasileira das Obras Psicológicas Completas de Sigmund Freud (Vol. XIX, pp.79-155). Rio de Janeiro, Brasil: Imago.

Freud, S. (1923/2007). O eu e o id. In:A. H., Luiz (Trad.). Escritos sobre a psicologia do inconsciente. Rio de Janeiro, Brasil: Imago (Vol. III, pp. 13-92).

Freud, S. (1930 [1929]/1996) O mal estar na civilização. In: J. Strachey (Ed.) e J. Salomão (Trad.). Edição Standard Brasileira das Obras Psicológicas Completas de Sigmund Freud (Vol. XXI, pp.67-150). Rio de Janeiro, Brasil: Imago.

Freud, S. (1933[1932]/1996). Novas conferências introdutórias sobre a psicanálise, conferência XXXI, A dissecção da personalidade psíquica. In: J. Strachey (Ed.) e J. Salomão (Trad.). Edição Standard Brasileira das Obras Psicológicas Completas de Sigmund Freud (Vol. XXII, pp.63-84). Rio de Janeiro, Brasil: Imago. 
Freud, S. (1940 [1938]/1996). Esboço de psicanálise. In: J. Strachey (Ed.) e J. Salomão (Trad.). Edição Standard Brasileira das Obras Psicológicas Completas de Sigmund Freud (Vol. XXIII, pp.153-223). Rio de Janeiro, Brasil: Imago.

Gerez-Ambertín, M. (2009). As vozes do supereu: na clínica psicanalítica e no mal-estar na civilização. (C. Stellla, Trad.). Rio de Janeiro, Brasil: Cia. De Freud.

Hegel, G. W. F. (1974). Estética: pintura e música VI. In: R. Álvaro (Trad.). Coleção filosofia e ensaios. Lisboa, Portugal: Guimarães \& Cia editores.

Lacan, J. (1953/1998). Função e campo da fala e da linguagem. In: R. Vera (Trad.). Escritos (pp.238-324). Rio de Janeiro, Brasil: Jorge Zahar.

Lacan, J. (1953-1954/2009). O seminário, livro I: os escritos técnicos de Freud. B. Milan (Trad.). Rio de Janeiro, Brasil: Zahar.

Lacan, J. (1956-1957/1995). O seminário, livro IV: a relação de objeto. D. E. Dulce (Trad.). Rio de Janeiro, Brasil: Jorge Zahar.

Lacan, J. (1957-1958/1999). O seminário, livoro V: As formações do inconsciente. In: R. Vera (Trad.) Rio de Janeiro, Brasil: Jorge Zahar.

Lacan, J. (1959-1960/2008). O seminário, livro VII: A ética da psicanálise. A. Quinet (Trad.). Rio de Janeiro, Brasil: Jorge Zahar.

Lacan, J. (1960/1998). Subversão do sujeito e dialética do desejo. In: R, Vera (Trad.). Escritos (pp.807-842). Rio de Janeiro, Brasil: Jorge Zahar.

Lacan, J. (1958-1959/2016) O seminário, livro VI: O desejo e sua interpretação. B. Claudia (Trad.). Rio de Janeiro, Brasil: Jorge Zahar.

Lacan, J. (1962-1963/2005). O seminário, livro X: A angústia. V. Ribeiro (Trad.). Rio de Janeiro, Brasil: Jorge Zahar.

Lacan, J. (1964/2008). O Seminário, livro XI: Os quatro conceitos fundamentais da psicanálise. M.D, Magno (Trad.). Rio de Janeiro, Brasil: Jorge Zahar.

Lacan, J. (1965-1966). O seminario, libro 13: El objeto del psicoanálisis. J, Tarella (Trad.). Buenos Aires, Argentina: Escuela Freudiana de la Argentina.

Lacan, J. (1966/1998). O estádio do espelho como formador da função do eu. In: R, Vera (Trad.). Escritos (pp.96-103). Rio de Janeiro, Brasil: Jorge Zahar.

Lacan, J. (1967). Breve discurso a los psiquiatras. R, Pablo; P, Roberto; e C, Félix (Trads.) Inédito. Recuperado em: http:/ / www.teebuenosaires.com.ar/ biblioteca/trad_07.pdf.

Lacan, J. (1967/2003). Alocução sobre as psicoses na criança. In: V, Ribeiro (Trad.) Outros Escritos. (pp.359-368). Versão final: Angelina Harari e Marcus Andre Vieira; preparação do texto: Andre Telles. Rio de Janeiro, Brasil: Jorge Zahar.

Lacan, J. (1968-1969/2008). O seminário, livro XVI: de um Outro ao outro. V. Ribeiro (Trad.) Rio de Janeiro, Brasil: Jorge Zahar. 
Lacan, J. (1971/2009). O Seminário, livro XVIII: de um discurso que não fosse semblante. V. Ribeiro (Trad.). Rio de Janeiro, Brasil: Jorge Zahar.

Lacan, J. (1975/1985). O seminário, livro XX: mais, ainda. M.D. Magno (Trad.). Rio de Janeiro, Brasil: Jorge Zahar.

Lacan, J. (1975-1976/2007). O seminário, livro XXIII: O sinthoma. S. Laia (Trad.). Rio de Janeiro, Brasil: Jorge Zahar.

Lacan, J. (1976-1977). Lo Seminário XXIV: Lo no sabido que sabe de la una-equivocación se ampara em la morra. Buenos Aires, Argentina: ENAPSI - Entidad de Acción Psicoanalítica.

Laznik, M-C. (2000). A voz como primeiro objeto da pulsão oral. Estilos da Clínica - Revista sobre a infância com Problemas: dossier Clínica de Bebês, V (8), 80-93. Recuperado em: http://pepsic.bvsalud.org/pdf/estic/ v5n8/08.pdf.

Laznik, M-C. (2004). A voz da sereia: o autismo e os impasses na constituição do sujeito. Salvador, BA, Brasil: Álgama.

Miller, J-A. (1994). Percurso de Lacan: uma introdução. A. Roitman (Trad.) Rio de Janeiro, Brasil: Jorge Zahar.

Miller, J-A. (1989/2013). Lacan e a voz. Opção Lacaniana online nova série, 4(11), 1-13. Recuperado em: http:/ / www.opcaolacaniana.com.br/pdf/ numero_11/voz.pdf.

Oliveira, L.E.C. (2017). Sobre o esquecimento inesquecível da voz do Outro: o objeto voz na psicanálise. Dissertação não publicada. Universidade Católica do Rio de Janeiro, Rio de Janeiro, Brasil. Recuperado em: http:/ /www2. dbd.puc-rio.br/pergamum/tesesabertas/1512099_2017_completo.pdf.

Poizat, M. (1996). La voix sourde - La societé face à la surdité. Paris, France: Métailié.

Porge, E. (2014). Voz do eco. V. Viviane (Trad.). Campinas, SP, Brasil: Mercado das letras.

Quignard, P. (1999). Ódio à música. A. M. Scherer (Trad.) Rio de Janeiro, Brasil: Rocco.

Schreber, D. (1905/1995). Memórias de um doente dos nervos. M. Carone (Trad.). Rio de Janeiro, Brasil: Paz e terra.

Vieira, M.A. (2009). A presença do Outro. In: Curso livre do ICP-RJ na Seção-Rio da Escola Brasileira de Psicanálise, Inédito.

Vivès, J-M. (2012a). La voix sur Le divan: Musique sacrée, opéra, Techno. Paris, France: Aubier.

Vivès, J-M. (2012b). A voz e a música como dispositivos terapêuticos. M, Edimilson (Trad.). Recuperado em: http://www.fcm.unicamp.br/fcm/noticias/2015/voz-e-musica-como-dispositivos-terapeuticos?language=en.

Vivès, J-M. (2012c). A voz na clínica psicanalítica. Rio de Janeiro, Brasil: Contra Capa. 
Vivès, J-M (2016). O que é escutar vozes? Biblioteca Virtual do Instituto Vox de Pesquisa em Psicanálise. São Paulo. Recuperado em: http://voxinstituto.com.br/wp-content/uploads/2018/03/jmvives-oqueeescutarvozes_15.pdf. 